\title{
Does the way in which a firm interacts with its network partners influence its formulation of product innovation strategies?
}

\section{XueFeng Liu}

School of Management, Xiamen University, Xiamen 361005, PR China

E-mail: liuxuefeng@xmu.edu.cn

* Corresponding author

\section{Jing Cai}

University of Aberdeen Business School, Edward Wright Building, AB24 3QY, Aberdeen, United Kingdom. E-mail: jing.cai@abdn.ac.uk

\author{
Alison U. Smart \\ Adam Smith Business School \\ University of Glasgow, \\ Main Building, Glasgow, G12 8QQ, United Kingdom. \\ E-mail: alison.smart@glasgow.ac.uk
}

\begin{abstract}
This paper examines how network embeddedness influences firms' formulation of product innovation strategies. We explored firms' interactions with two types of network partners (business partners and technical partners) along two dimensions (relational and structural) of network embeddedness. The moderating effect of change dynamics on the interplay between network embeddedness and firms' strategy formulation was also examined. Data were collected from 310 firms in five Chinese high-tech and three traditional manufacturing industries. Our findings indicate that strong, weak and nonredundant contacts are conducive to the formulation of product innovation strategies. Firms' interaction with technical and business partners is also positively associated with the strategy formulation. However, geographic dispersion of partners has no impact. In addition, although technological dynamics exert a positive moderating effect on the relationship between network embeddedness and the formulation of product innovation strategies, radical changes in market conditions had no impact on firms' engagement with network contacts, and consequently on strategy formulation.
\end{abstract}

Keywords: network embeddedness; the formulation of product innovation strategy; change dynamics; emerging economy 


\section{Acknowledgement:}

\section{Biographical notes:}

Xuefeng Liu is a Full Professor in the School of Management, Xiamen University, China, and a member of the Academy of Management. He received his PhD degree in Management from Zhejiang University, China. His recent main research interests focus on global manufacturing, strategic management and innovation management. He has published several research papers about network embeddedness and innovation in international journals in English, and has participated in several research programmers supported by National Natural Science Foundation of China.

Dr. Jing Cai is a Senior Lecturer in Management Studies at the University of Aberdeen Business School. She holds a $\mathrm{PhD}$ in technology management from the University of Sheffield. Her research interests include technology strategy, firm dynamic capability and supplier management strategy. She has undertaken several research projects including 'Supplier management strategies and competitive advantage' funded by The Carnegie Trust; and 'Corporate governance and technological development in China', funded by the UK Economic and Social Research Council (in collaboration with Professor Andrew Tylecote at Sheffield University and Professor Wu Guisheng at Tsinghua University). Jing is currently a co-investigator for a Knowledge Transfer Partnership project with colleagues at the University of Aberdeen.

Dr Alison Smart is a Senior Lecturer at the Adam Smith Business School, University of Glasgow. Alison is currently a co-investigator for ASSURE with colleagues at the University of Aberdeen, a research project funded as part of the dot.rural hub at Aberdeen. She collaborates with a number of different researchers from several universities in work looking at process innovations, particularly innovations at the interface of organizations, and innovations in supply chains for both goods and services. Alison has a doctorate in chemistry and before moving into university research worked as an industrial research and development chemist.

\section{Introduction}

This paper contributes to contemporary debates in product innovation management. The first debate, on open innovation, suggests that firms should seek external ideas for innovation (Chesbrough, Vanhaverbeke, and West, 2006). It is recognised that suppliers, customers and technical partners (such as government research institutes and universities) are important sources for new product development (NPD) (supplier involvement: see Wynstra, Corswant, and Wetzels, 2010; customer involvement: see Von Hippel, 1986; Garmer, Dahlman, and Sperling, 1995; technical partners: see Andersson, Forsgren, and Holm, 2002). How firms utilise these network resources to facilitate product innovations is largely unexplored (Barczak, 2012). The literature on how networks should be configured to effectively use sources of new ideas in strategy formulation is particularly sparse. To address this limitation this paper uses both relational and structural dimensions to examine the effect of network 
embeddedness on the formulation of product innovation strategies of firms.

The second issue is the emphasis of research into product innovation. A recent review of the product innovation literature found that many existing studies of product innovation emphasized NPD implementation and the post-launch stages (Spanjol, Qualls, and Rosa, 2011). Product innovation strategies received much less attention. Page and Schirr (2008) found only 5\% of all product innovation studies between 1989 and 2004 investigated issues around the formulation of product strategy. Our own search of strategy journals found no additional articles. This paper aims to enrich the understanding of strategy formulation by examining the association between network embeddedness and the formulation of product innovation strategies of firms.

A third issue is that network embeddedness and product innovation strategies are contingent on changes in the external environment (Rowley, Behrens, and Krackhardt, 2002). Looking at environmental changes, technological advances and market turbulence may influence the way in which firms interact with network players, resulting in different impacts on strategy formulation. The majority of product innovation research is currently biased towards North American and Western European contexts (Garczak, 2012). In order to have a fuller understanding of the developed theories in NPD, there is a need to extend the research to non-western contexts (Song, Im, Bij, and Song. 2011), and particularly to major emerging economies such as China (Garczak, 2012).

Building on current research in the open innovation (network embeddedness) and product innovation management (Andersson et al., 2002; McEvily and Zaheer, 1999; Garczak, 2012) literature, we addressed two research questions:

(1) How do networks influence the formulation of product innovation strategies by firms in vertically embedded relationships with suppliers, customers and/or technical partners), and by its network structure?

(2) How do environmental changes moderate the relationship between network embeddedness and the formulation of product innovation strategies by firms?

Our research explores these two questions in the context of 310 firms in eight Chinese manufacturing industries.

Section 2 of the paper reviews the literature review and develops hypotheses. Section 3 describes the data collection and describes the variables. Section 4 presents our main findings. Section 5 discusses the results, presents the main conclusions and suggests future research.

\section{Theory and Hypotheses}

The formulation of product innovation strategies is a key stage in innovation management, as it sets out the direction of product development that leads to economic success by improving firm competitiveness. The formulation can be influenced by (i) where information is acquired (internal vs. external; business partners vs. technical partners) to develop new products; and (ii) the way the focal firm interacts with partners, such as the relationship formed with its partners and the position of the firm in the network.

There are two important sources of new information: (i) customers and suppliers who develop relationships with firms through purchases or sales (Wynstra et al., 2010, Von Hippel, 1986); and (ii) technical partners (e.g. government research institutions and universities, Andersson 
et al., 2002) who collaborate with firm with the intention of introducing product innovations, and who are not involved in any kind of business purchase or sale with firms. Andersson et al. (2002) introduced the concepts of business embeddedness and technical embeddedness to differentiate between these two types of network interactions.

Embeddedness is understood as the level of social interaction in inter-firm relationships (Uzzi, 1996), and can be examined on two dimensions: 1. Relational embeddedness relates to the closeness of the dyadic relationships between a focal firm and its contacts (Moran, 2005). Strong ties between firms are generally perceived as facilitating the transfer of tacit knowledge (Gilsing and Nooteboom, 2006). Weak ties are essential for transmitting information between different social or economic circles (Burt 1992); 2. Structural embeddedness relates to the influence of the architecture of a network on a member firms' economic activity (Uzzi, 1996). A firm's position in a network is important in receiving, transmitting, and controlling information (Gilsing et al 2008). Firms in a central position are better informed about information in the network, and a focal firm can disseminate information that facilitates joint innovation effort with partners (Wang and Chen 2015). In this research we use mutual adaptation and infrequency of interaction as two indicators of structural embeddedness, and non-redundant contacts and geographic dispersion as two indicators of structural embeddedness.

\subsection{Relational embeddedness}

\subsubsection{Strong ties and mutual adaptation}

To specify the effect of tie strength, we propose that organizations exhibit 'mutual adaptation', and argue that when a focal firm and its business or technical partners have strong ties to one another they are more likely to adjust their own working behaviours to achieve a high degree of compatibility. This mutual adaptation requires both parties to increase their commitment to, and dependence on, each other (Holm, Eriksson, and Johanson, 1999). Such relation-specific adjustments largely exist in close and trusting relationships. We define 'mutual adaptation' as 'mutual investment by two or more network contacts to adapt to specific organizational needs by modifying processes and procedures to achieve mutual value creation'. The purpose of mutual adjustments is to bring about a better match between partners (Mukherji and Francis, 2008).

In the product innovation literature, strong ties are generally perceived as being associated with innovation execution (Hansen, 1999); they facilitate trouble-shooting and problem-solving (Takeishi, 2001) and the transfer of tacit knowledge (Gilsing and Nooteboom, 2006), all of which are desirable for the effective realisation of product innovations (Hansen, 1999). The traditional view, however is that, strong ties result in a high level of overlapping information (Granovetter, 1973), impeding the search for new information. This view is contradicted by studies suggesting that strong ties may provide access to new information (Cai, Smart and Liu 2014). It can be argued that the formulation of new product strategies is determined by both access to new information and by a firm's capabilities in the execution of new product development projects, both of which can be facilitated by mutual adaptation. 
The search for new information requires the gathering of both diverse and in-depth information relating to NPD. In-depth information tends to be product specific that may lead to deeper knowledge of the product area (Rowley et al., 2000), meaning that any search is likely to be limited in breadth but can go deeper in its quest for subject-based expertise. Mutual adaptation gives significant advantages: a focal firm becomes more familiar with its customers' specific needs, and its suppliers' and technical partners' working patterns. This increasing familiarity enables the focal firm to gain a better knowledge of the nature and location of partners' expertise, which may be new to the focal firm. Furthermore, mutual adaptation is a learning process; when a focal firm interacts with suppliers and technical partners it may identify gaps in its own internal resources and knowledge. Suppliers and partners can fill these gaps and assist the firm in fulfilling customer needs. The gaps offer good opportunities for new product ideas and therefore may enable the focal firm to formulate further product development strategies.

Execution of new product projects is facilitated by timely integration of knowledge with network partners (Eisenhardt and Tabrize, 1995; Hansen, 1999). Integration requires coordination between different organizational units to pool resources (Autry and Griffis, 2008). When different contacts (suppliers, customers and technical partners) engage in a collaborative adaptation process, there are always conflicts and mismatches as a consequence of the idiosyncratic behaviour of individuals or of different working patterns. The experience and knowledge that partners derive from adapting to one another's behaviour or working patterns can develop problem identification skills, the ability to resolve problems through effective communication, and competence to coordinate and integrate disparate resources and tasks (Ettlie and Pavlou, 2006). These accumulated skills and competences in project execution can increase organizations' confidence and make them more willing to venture into new product innovations that result in the formulation of new strategies (Chung and Kim, 2003)

Given this literature base we propose that (see Figure 1):

Hypothesis 1: In strong tie relationships, mutual adaptation between network partners (suppliers, customers and technical partners through business or technical embeddedness) has a positive effect on firms' formulation of product innovation strategies.

\subsubsection{Weak ties, infrequency of interaction and innovation}

Previously we noted that strong ties are advantageous in the search for specific, in-depth knowledge. However, strong ties impede the acquisition of information from diverse sources (Granovetter, 1973). Granovetter (1973) proposes frequency of interaction as one of the indicators measuring tie strength; given limited time and effort, maintaining relationships through frequent interactions with existing suppliers and technical partners limits the time a focal firm has to create the new ties required to transmit information between different social and industrial backgrounds (Vanhaverbeke et al. 2012). In product innovation Burt (1992) has proposed that weak ties facilitate exploration of novel, emerging opportunities, and breaking away from established routines.

Less frequent interactions between a firm and contacts in its network are more likely if the firm and its contacts operate in different economic or social circles (Burt, 1992). For example, infrequent interactions with a wide range of customers enhance firms' chances of 
getting access to information that goes beyond current market segments when compared to expending equivalent effort with a small number of partners in deep searches (Capaldo, 2007): exposure to more socially distant and less familiar suppliers or technical partners can raise awareness of new trends in technological development and available resources in the market. This exposure can engender the formulation of product innovation strategies (Borgatti and Halgin, 2011). This leads to Hypothesis 2 (see Figure 1):

Hypothesis 2: In weak tie relationships, infrequent interactions between network partners (through business or technical embeddedness) have a positive effect on the formulation of product innovation strategies.

\subsection{Structural embeddedness}

\subsubsection{Network position and non-redundant contacts}

In the previous section we suggested that infrequent interactions increase firms' exposure to potentially useful information. But whether firms can be better informed about and grasp new opportunities depends on two things: their ability to increase their exposure to large volumes of information, and their ability to manage diverse sources of information given limited resources. In this context, McEvily and Zaheer (1999:1137) propose the concept of nonredundant contacts - 'the extent to which the contacts in a focal firm's network are not linked to each other' - as an indicator of the focal firm's strategic position in its network and its access to diverse information. They argue that firms rich in non-redundant contacts should have greater informational benefits than firms that have networks without non-redundant ties. Non-redundant contacts provide a focal firm with the means to reach a large number of indirect contacts and therefore to gain access to a large volume of information (McEvily and Zaheer, 1999). Firms that maintain connections to heterogeneous information sources enhance their potential to gain knowledge across different market segments, technologies, and organizational practices (Capaldo, 2007).

The management of non-redundant contacts enables a firm to identify, select and manage useful information sources. Maintaining too many ties is time consuming and costly, but having insufficient ties limits access to information. Firms therefore need to be able to recognize and select new suppliers, customers or potential technical partners that can add the most value, and be willing to eliminate ties when they become highly redundant. We propose that a firm's possession of non-redundant contacts reflects its ability to both increase its exposure to information sources and to effectively obtain and manage information sources. Since non-redundant contacts are likely to possess different information about novel products and new market segments they have a positive impact on firms' initiation of product innovation strategies. We therefore hypothesize that (see Figure 1):

Hypothesis 3: Non-redundant contacts (through business or technical embeddedness) in a firm's network are positively associated with the formulation of product innovation strategies.

\subsubsection{Network structure, geographic dispersion and innovation}


Geographic dispersion indicates the distance between two network contacts (Torre and Rallet, 2005). In this study we examined the influence of geographic dispersion on firms' motivation to pursue product innovation. Gilsing et al., (2008) argue that firms' adsorptive capabilities decline with geographic distance; geographic proximity facilitates the transfer of tacit knowledge, which is best transmitted through intensive communication (Kogut and Zander, 1992; Ganesan et al., 2005). However, research has suggested that close proximity of contacts causes network contacts to become too inward looking, weakening their ability to sense new product opportunities so that firms lose their innovative capacities and cannot respond to new developments (Boschma, 2005). This is because the development of suppliers, customers and technical partners is largely influenced by local culture, infrastructures and institutions. This may cause firms' to focus too heavily on satisfying local tastes, rather than on exploring options for wider innovation (Ganesan et al., 2005). When firms seek out contacts that are geographically dispersed and linked into fundamentally different information sources, they have a better chance of discovering unique opportunities for innovation. This concurs with McEvily and Zaheer's (1999) argument that the diversity of information received by a firm is likely to increase with geographic dispersion. The advantages from enhanced adsorptive capacity and transfer of tacit knowledge resulting from proximity are important in the realisation of innovation, and may indirectly be conducive to the formulation of product innovation strategies by enhancing innovation capability (see discussion in Section 2.1.1). However, we propose that geographically dispersed network contacts may directly influence the acquisition of more diverse information and the generation of different perspectives. We therefore hypothesize (see Figure 1):

Hypothesis 4: Geographic dispersion of network contacts (through business or technical embeddedness) is positively associated with the formulation of product innovation strategies.

\subsubsection{Change dynamics}

Dess and Beard (1984) define change dynamics in terms of two dimensions - the extent of change stability and the extent of change predictability. Change stability refers to the extent to which events in an environment occur frequently (Damanpour and Gopalakrishnan, 1998, Mintzberg, 1979). Predictability indicates the extent to which events occur as expected, and for which outcomes can be foreseen in advance (Mintzberg, 1979). Moorman and Miner (1997) argue that change dynamics mainly come from two areas: technological and market changes. Technological changes reflect the uncertainty involved in technological development (Jaworski and Kohli, 1993): market changes refer to shifts in market competition and customer tastes (ibid., 1993). The magnitudes of both changes influence the impact of network embeddedness on the formulation of product innovation strategies of firms. For example, in a stable environment, where both market and technological changes are predictable, the external impetus for change is weak and the rate of new product innovation may be low (Damanpour and Gopalakrishnan, 1998). Moreover, if an organization primarily chooses incremental modification of existing product architectures to improve features it generally relies on its own accumulated knowledge and experience, rather than seeking resources and skills from network partners. In contrast, when both the technology and the market change frequently and irregularly the rate of product innovation may be high (Damanpour and Gopalakrishnan, 1998). In this case, a firm's own experiences and resources 
may be insufficient to support the speed and magnitude of change, and the firm needs to look actively for new information, acquire complementary resources and examine emerging innovation opportunities. We propose that when technological and market changes are unstable and unpredictable a firm is more likely to engage with its network partners. This strong network embeddedness results in high rates of product innovation. We therefore hypothesize (see Figure 1) that:

Hypothesis 5: High change dynamics have a positive moderating effect on the relationship between network embeddedness and the formulation of product innovation strategies.

We thus have five hypotheses that link network embeddedness and the formulation of product innovation strategies (see Figure 1).

\section{Insert Figure 1}

\section{Research Design and Data Collection}

\subsection{Research Setting}

The research was carried out in manufacturing firms in Shanghai, and in the Chinese provinces of Zhejiang and Jiangsu. All three regions are in the affluent Yangtze River Delta, which is regarded by many as the backbone of traditional manufacturing operations in China. In the last thirty years the regions have developed into popular incubation centres for hightechnology industries. The three locations have similar levels of affluence, so any differences in firm performance should not be attributable to differences in access to resources or preferential local policies.

\subsection{Data Collection}

Data was collected using a questionnaire. To formulate the questionnaire four case studies were undertaken to explore the relationships between network embeddeness and the formulation of product innovation strategies. At the same time the literature on theories and discussions relating to the embeddedness and the formulation of product innovation strategies was reviewed. Results and findings from the case studies and the literature review were then combined, and a draft questionnaire was designed. The draft questionnaire was discussed with four specialists in network embeddedness and firm innovation from the Innovation Research Centre at Zhejiang University, China, and four senior managers from different firms (not the four case study companies). The questionnaire was then piloted to top managers in five firms. Feedback on wording, terminologies and format was incorporated into the final version of the questionnaire.

To test the hypotheses we use stratified sampling (related to company age and size) to increase sampling efficiency. The sampling frame included all manufacturing firms in five high-tech industries (software, electronics, telecommunications, pharmaceutical, new materials) and three traditional industries (machinery, chemical, textiles) in Shanghai, Zhejiang and Jiangsu. These 8 industries were selected as they were regarded as key strategic industries in three regions. To increase the response rate, we used a combination of 
convenience and random sampling strategies in each stratified category. First, one of the researchers used his contacts with firms in the targeted industries. These included thirty-two questionnaires distributed in person (100\% response rate). Second, during the course of the research, the Management School at Zhejiang University recruited more than three hundred Executive MBA students from the three regions. A quarter of the students worked in the eight industries in the target locations: seventy-two of these agreed to participate in the research. A brief explanation of the study and the questionnaire was undertaken in class to enhance understanding of the questions and to improve the accuracy of the data. Third, the questionnaire was also sent to 918 firms in the selected sectors. Our total sampling size counts to $70 \%$ of the population.

A total of 310 firms responded to the questionnaire (from both the convenience and random samples). Of the respondents, $52.6 \%$ of the firms were in traditional industries and $47.4 \%$ in high-technology sectors; $45.2 \%$ of firms were located in Zhejiang, $31.6 \%$ in Jiangshu and $23.2 \%$ in Shanghai. The majority of firms had existed for 6-10 years (34.5\%) or $11-15$ years $(33.5 \%)$. Of the respondent firms, $27.7 \%$ had between 1,000 and 5,000 employees, 20.9\% had 501 to 1,000 employees, and 26.5\% had 101-500 employees. A t-test was used to examine whether there was any variation between the convenience sample and the random sample. The results showed no significant differences between the two sets of data in terms of company age $(\mathrm{t}=0.018 \mathrm{P}=0.894)$ and employee numbers $(\mathrm{t}=0.039 \mathrm{P}=0.845)$.

\section{Operational Measures}

\subsection{Relational network embeddedness (See Table 1)}

\section{(1) Mutual adaptation.}

We adopted two measures from Anderssonet.al.'s (2002) study, with adaptations to suit the setting of this research. First, we asked managers in Purchasing and Technical departments to assess the degree to which the firm has changed its work patterns because of interactions with its most important customers, suppliers and technical partners. A sevenpoint Likert scale from 1 (no change) to 7 (substantial change) indicated their perception of the scope of the changes. Second, we asked about the number of different functional areas that have direct contacts with customers, suppliers and technical partners. Andersson et al. (2002) have argued that if more functional areas are involved it implies a greater investment in the relationship. This measure was rated from 1 (none) to 7 (many).

\section{(2) Infrequency of interaction.}

To assess the infrequency of interaction we adopted McEvily and Zaheer's (1999: 1146) approach of using an overall interaction score. All respondents were first asked to identify the five most important sources of contacts and then they were asked to estimate for each contact the number of conversations per month. The average score was calculated as

Infrequency of interaction $=\frac{1}{\sqrt{\text { mean (conversations per month) }}}$ 


\subsection{Structural network embeddedness}

In assessing structural network embeddedness we used two measures adopted from McEvily and Zaheer (1999: 1146-1147)

\section{Insert Table 1}

\section{(1) Non-redundant contacts}

Each respondent identified no more than five of their most important contacts. We then asked if these people knew each other. A non-redundant contacts score was calculated as: Non-redundant contacts $=($ potential ties- actual ties $) /$ number of contacts

where 'potential ties' is total number of potential ties that may exist among contacts ( 0 to 10$)$, 'actual ties' is the number of ties that have actually developed among contacts ( 0 to 10$)$, and 'number of contacts' is the total number of contacts identified (0 to 5).

\section{(2) Geographic dispersion}

Respondents were asked to list the geographic distance travelled (in terms of hours) by car to each contact. We then computed average distances from respondents to their contacts. An aggregate geographic dispersion measure was calculated as:

Geographic Dispersion $=\sqrt{\text { mean (distance) }}$

\subsection{Innovation strategies}

Based on Miller (1986) and Utterback (1996), we designed measures to examine the importance of product innovation in formulating firm business strategy, the aggressiveness of product innovation strategy and R\&D expenditure. Apart from the R\&D ratio, which was rated in terms of seven percentage intervals, the other measures were rated using a Likert scale of from 1 (low) to 7 (high) (See Table 1).

\subsection{Change dynamics}

Two moderating variables were used to estimate the influence of technological and marketing changes on network embeddedness and innovation. Based on studies by Jaworski and Kohli (1993), measures designed to examine the risks involved in change dynamics were ranked from 1 (strongly disagree) to 7 (strongly agree) (see Table 1).

\subsection{Construct validity}

We first used Exploratory Factor Analysis (EFA) to test the construct validity. We conducted the principal component analysis with the Varimax rotation, and extracted factors with eigenvalues greater than one. As show in Table 1, two factors emerged in the EFA of Network embeddedness (mutual adaptation) and represented technical embeddedness and business embeddedness respectively, one factor emerged in the EFA of Product innovation strategies, and Two factors emerged in the EFA of Change dynamics representing technical dynamics and marketing dynamics respectively. The results also show all items are loaded onto their 
expected factors (relevant factor loadings are greater than 0.5). Furthermore, we deployed Confirmatory Factor Analysis (CFA) to test the discriminant validity of measures of mutual adaptation and change dynamics, which show two-factor model has better model fit than onefactor model (Netemeyer, Johnston and Burton, 1990). These results show that all measures were valid for the study.

\subsection{Construct reliability}

We used Cronbach's alpha to assess internal consistency. Our results show that all items of the scales designed for each variable satisfied the required construct reliability for multiple regressions (See Table 2).

\section{Insert Table2}

\subsection{Control variables}

Firm size, age and characteristics of industries and geographic locations were used as our control variables, with employee numbers as an indicator of firm size.

\section{Analysis}

We used multiple regression models to test the relationships between network embeddedness and the formulation of product innovation strategies by regressing different sets of measures in sequence. In order to check the effects of the two moderators on network embeddeness and firm innovation, and to avoid multicollinearity, we used change and network embeddedness as multiplier inputs for the multiple regression analysis (See Table 5). To verity multicollinearity, we checked the variance inflation factor for the independent variables in each regression model. Results showed that all variables in our analyses were within the recommended range $(<5)$, suggesting that the variance of estimated regression coefficients did not increase because of collinearity.

\section{Results}

Table 3 presents the descriptive statistics and the correlations between the variables used in the regression analyses.

\section{Insert Table3}

Hypothesis 1, 2 and 3 predicted that mutual adaptation, infrequency of interaction, nonredundant contacts (individually) would be positively related to the formulation of product innovation strategies. The three hypotheses were all supported in both business and technical embedded relationships. Hypothesis 4 predicted a positive association between geographic dispersion and firms' adoption of innovation strategies, and was not supported (see Table 4).

\section{Insert Table4}

Hypothesis 5 predicted that change dynamics would have a positive moderating effect on the relationship between network embeddedness and the formulation of product innovation 
strategies. Our results suggest that when technological changes are fast and unpredictable, firms exhibit strong engagement with technical partners, and this increased engagement facilitates the formulation of product innovation strategies (see Table 5). However a similar moderating effect was not found for market dynamics (only one measure, geographical dispersion, is significant). This implies that when market changes become more dynamic, firms do not significantly adjust the way in which they interact with suppliers or with customers. Consequently small changes in business embeddedness have less of an impact on firms' initiatives to formulate new product innovation strategies than do changes in technological embeddedness. Interestingly, the moderating effect of technical and market dynamics is strong on one measure of structural embeddedness - geographical dispersion. When technology and market changes are fast and unpredictable, geographically distant partners are more likely to embark on the formulation of product innovation strategies.

\section{Insert Table5}

\section{Discussion}

Previous research has stressed the advantages of weak ties in sourcing new information for product innovation (Hensen, 1999; Antcliff et al., 2007). Our results suggest that both strong and weak ties facilitate strategy formulation but in different ways that trusting relationships deepen information search and weak and infrequent contacts broaden information exploration. It provides good reasoning against the traditional view that strong ties impede innovations and reconfirms the positive effect of weak ties on innovation in Chinese context.

Our tentative explanation is that firms relied on strong ties to deepen their expertise in the search for new product opportunities in established product lines. Mutual adaptation (through strong ties) may achieve this in several ways. First, specific knowledge or expertise relating to new product design may be largely tacit. This tacitness can become an obstacle to a focal firm accessing knowledge from the network. For example, suppliers may decide not to share knowledge because this limits the risk of knowledge spillovers via customers to competitors (Dyer and Hatch, 2006). Even if both parties are willing to share, the extent and type of knowledge shared depends on trust. Mutual adaptation requires relation-specific investments (Holm et al., 1999). These investments only give a return in trusting relationships (Donada, 2002). Therefore mutual adaptation through relationship-specific investments may require continued efforts to build trust and develop the willingness of network contacts' to share key information with the focal firm, thus facilitating the formulation of product innovation strategies. Second, the scope of a search for specific, product-related information is likely to be limited in breadth, but deep in its quest for subject-based expertise. When deep searching is required, mutual adaptation gives greater advantages. Through adapting to others' working processes, a focal firm will have a fuller understanding of the nature and location of a network contact's expertise, thus enabling better access to that expertise. Third, mutual adaptation, shared communication protocols and organizational systems promote information exchange that is important to new product ideas (Dhanaraj, Marjorie, Steensma, and Tihanyi, 2004).

Weak ties (through infrequent interactions) with network contacts benefit focal firms by giving them greater exposure to the wider information that is essential to generate emerging 
product opportunities (Schilling and Phelps, 2007). However, a firm's capability in identifying information about potential opportunities depends on its capacity to sense relevant information about new technical or market trends. Gathering new information from diverse sources is enabled by non-redundant contacts at key nodes of a network (McEvily and Zaheer, 1999; Capaldo, 2007).

We also found that the geographical location of network contacts had no impact on the formulation of product innovation strategies. This finding differs from McEvily and Zaheer's (1999) observation that geographic dispersion brings fresh information and knowledge and is conducive to innovation by firms. Our tentative explanation of this difference is that there have been major advances in information technologies since McEvily and Zaheer conducted their research. These advances have made it easier and quicker for firms to access distant information. Further research is needed, however, to investigate to what extent advanced information technologies remove geographical barriers and help information to be transmitted quickly.

Existing research on the general environmental influence on firms' innovation activities suggests a positive association between the increased external impetus for change and firms' innovation initiatives (Damanpour and Gopalakrishnan, 1998). This suggestion is only partially supported by our empirical results. We found that changes in market conditions had no impact on firms' engagement with network contacts, and consequently on the formulation of product innovation strategies. Increasing advances in technology, however, resulted in focal firms increasing their intensity of interaction with network contacts. One possible explanation of this observation is that, in the Chinese market, the magnitude of change caused by technological advances is more significant than that from market pressures (e.g. changes in customers' tastes or in market competition).

Our findings also provide empirical evidence to support March and Simon (1958) and Chesbrough et al's (2006) open innovation theory, which suggest that external knowledge has become increasingly important to innovation. We find that both business embeddedess and technical embeddedness facilitate the formulation of product innovation strategies. In developing relationships with technical partners such as universities and government research institutions, firms engage in research to sense the latest technology developments (Cohen, 1995).

This study contributes to research on production innovation strategy in several ways. First it explored how network architecture influences firms' formulation of product innovation strategy. In this context we examined influences from both relational and structural dimensions of networks through business and technical contacts of firms involved in product innovation. Using a network perspective in such studies is an undeveloped approach (Barczack, 2012). Second, little attention has been paid to the front end of product innovation. This research addressed this limitation by looking at the formulation of strategies (Page and Schirr, 2008). Third, the research examined the moderating effect of technological and market dynamics on the relationship between network embeddedness and product innovation strategy, thus providing a fuller understanding of the interplay between networks and the formulation of product innovation strategies.

This research has important implications for existing studies of networks and of firms' product innovation strategies, but is limited in several aspects. First, our sampled firms all came from three economically developed areas in China (Zhejiang and Jiangsu provinces and Shanghai). These three regions have the characteristics of developed nations. Therefore, the conclusions and implications of the study may not be relevant to weaker, emerging 
economies. Second, in this research, we examined the impact of network embeddedness on the formulation of product innovation strategies. Further work is needed to examine how network configuration relates to the implementation of different types of product innovation strategies. Future studies could also focus on how network structure influences firms' capacity for innovation and, consequently, firm performance.

\section{References}

Andersson, U., Forsgren, M. and Holm, U.2002."The strategic impact of external networks: Subsidiary performance and competence development in the multinational corporation."Strategic Management Journal23(11): 979-996.

Antcliff, V., Saundry, R. and Stuart, M. 2007. "Networks and social capital in the UK television industry: The weakness of weak ties."Human Relations60(2):371-393.

Autry, C. W. and Griffis, S. E. 2008." Supply chain capital: The impact of structural and relational linkages on firm execution and innovation."Journal of Business Logistics29(1): 157-173.

Baker, N. R. and Pound, W. H. 1964."R\&D project selection: where we stand.”I. E. E. E. Transactions on Engineering ManagementEM-11: 124-134.

Barczak, G. 2012. "The future of NPD innovation research."Journal of Product Innovation Management29(3): 355-357.

Borgatti, S. P. and Halgin, D. S. 2011. "On network theory."Organisation Science22(5): 1168-1181.

Boschma, R. A. 2005. "Proximity and innovation: a critical assessment."Regional Studies39(1): 61-74.

Burt, R. S. 1992. Structural holes: The social structure of competition.Cambridge, MA: Harvard University Press.

Cai, J., Smart, A and Liu, X.F.2014. "Innovation exploitation, exploration and supplier relationship management."International Journal of Technology Management66(2/3): 134155.

Capaldo A.2007. "Network structure and innovation: The leveraging of a dual network as a distinctive relational capability."Strategic Management Journal28(6):585-608.

Chesbrough, H., Vanhaverbeke, W. and West, J.2006.Open innovation: Researching a new paradigm.Oxford University Press.

Chung, S. and Kim, G. M.2003. “Performance effects of partnership between manufacturers and suppliers for new product development: The supplier's standpoint."Research Policy 32: 587-603.

Cohen, W.D.1995."Empirical studies of innovation activities, in Stoneman P. (ed.)."Handbook of the economics of innovation and technical change.Oxford: Blackwell.

Damanpour, F. and S. Gopalakrishnan.1998. "Theories of organizational structure and innovation adoption: The role of environmental change."Journal of Engineering Technological Management, 15: 1-24. 
Dess, G. G. and Beard, D. W.1984. "Dimensions of organizational environment."Administrative Science29: 52-73.

Dhanaraj, C., A. L. Marjorie, H. K. Steensma and L. Tihanyi. 2004."Managing tacit and explicit knowledge transfer in IJVs: The role of relational embeddedness and the impact on performance."Journal of International Business Studies 35:428-442.

Donada, C.2002. "Generating cooperative gain in a vertical partnership: A supplier's perspective."Canadian Journal of Administrative Sciences 19(2):173-183.

Dyer, J. H. and Hatch, N. W.2006."Relation-specific capabilities and barriers to knowledge transfers: Creating advantage through network relationships."Strategic Management Journal27: 701-719.

Eisenhardt, K. M. and Tabrizi, B. N.1995."Accelerating adaptive processes: Product innovation in the global computer industry."Administrative Science Quarterly40: 84-110.

Ettlie, J. E. and Pavlou, P. A.2006."Technology-based new product development partnerships.”Decision Sciences37: 117-147.

Ganesan, S., A. J. Malter and Rindfleisch, A. 2005."Does distance still matter? Geographic proximity and new product development." Journal of Marketing69(4): 44-60.

Garczak, G.2012."The future of NPD/innovation research."Journal of Product Innovation Management29(3):355-357.

Garmer, K., Dahlman, S. and Sperling, L.1995. "Ergonomic development work: Coeducation as a support for user participation at a car assembly plant. A case study."Applied Ergonomics 26(6): 417-423.

Gilsing, V., and Nooteboom, B. 2006."Exploration and exploitation in innovation systems: The case of pharmaceutical biotechnology." Research Policy 35(1): 1-23.

Gilsing, V., Nooteboom, B., Vanhaverbeke, W., Duysters, G. and Oore, A. V. D.2008."Network embeddedness and the exploration of novel technologies: Technological distance, between centrality and density."Research Policy37: 1717-1731.

Granovetter, M. 1973.“The strength of weak ties.”American Journal of Sociology 78: 13601380.

Hansen, M. T.1999. "The search-transfer problem: The role of weak ties in sharing knowledge across organization subunits."Administrative Science Quarterly44(1):82-111.

Holm, D. B., Eriksson, K.andJohanson, J. 1999.“Creating value through mutual commitment to business network relationships.”Strategic Management Journal 20: 467-486.

Jaworski, B. J. and Kohli, A. K.1993."Market orientation: Antecedents and consequences.”Journal of Marketing 57:53-71.

Kogut, B. and Zander, U.1992."Knowledge of the firm, combinative capabilities, and the replication of technology."Organization Science3(3): 383-397.

Levin, D. Z. and Cross, C. 2004."The strength of weak tie you can trust: the mediating role of trust in knowledge transfer."Management Science, 50(11): 1477-1490.

March, J. G. and. Simon, H. A. 1958.Organizations. New York: Wiley.

McEvily, B. and Zaheer, A.1990."Bridging ties: A source of firm heterogeneity in competitive capabilities.”Strategic Management Journal20: 1133-1156. 
Miller, D.1986."Configurations of strategy and structure: Towards a synthesis."Strategic Management Journal7(3): 233-249.

Mintzberg, H.1997.The structuring of organizations.Prentice-Hall, Englewood Cliffs, NJ.

Moorman, C. and Miner, A. S. 1997."The impact of organizational memory on new product performance and creativity."Journal of Marketing ResearchXXXIV(February): 91-106.

Moran, P.2005. "Structural vs relational embeddedness: Social capital and managerial performance."Strategic Management Journal26: 1129-1151.

Mukherji, A. and Francis, J. D.2008."Mutual adaptation in buyer-supplier relationships."Journal of Business Research 61: 154-161.

Netemeyer, R., Johnston, M., \& Burton, S. 1990."Analysis of role conflict and role ambiguity in a structural equations framework." Journal of Applied Psychology 75: 148-157.

Page, A. L. and Schirr, G. R.2008."Growth and Development of a Body of Knowledge: 16 Years of New Product Development Research, 1989-2004*."Journal of Product Innovation Management25(3): 233-248.

Price, D. J. 1963. Little Science, Big Science. New York and London: Columbia University Press.

Rowley, T., Behrens, D. and Krackhardt, D. 2002."Redundant governance structures: An analysis of structural and relational embeddedness in the steel and semiconductor industry."Strategic Management Journal22: 369-386.

Schilling, M. A. and Phelps, C. C. 2007.“Interfirm collaboration networks: The impact of large-scale network structure on firm innovation."Management Science 53: 1113-1126.

Song, M., Im, S., Bij, H.V. D. and Song, L. Z.2011."Does Strategic Planning Enhance or Impede Innovation and Firm Performance?"Journal of Product Innovation Management28(4):503-520.

Spanjol, J., Qualls, W.J. and Rosa, J.A. 2011."How many and what kind? The role of strategic orientation in new product ideation."Journal of Product Innovation Management 28(2):236-250.

Takeishi, A. 2001."Bridging inter-and intra-firm boundaries: Management of supplier involvement in automobile product development."Strategic Management Journal22(5):404-433.

Torre, A. and Rallet, A.2005."Proximity and localization."Regional Studies,39: 47-59.

Uttertack, J. M.1996.Mastering the dynamics of innovation. Harvard Business Press.

Uzzi, B.1996."The source and consequences of embeddedness for the economic performance of organizations: The network effect."American Sociological Review 61: 674-698.

Vanhaverbeke, W., Silsing, V. and Duvsters, G.2012."Competence and governance in strategic collaboration: The differential effect of network structure on the creation of core and noncore technology."Journal of Product Innovation Management29(5): 784-802.

Von Hippel, E. 1986."Lead users: A source of novel product concept."Management Science 32: 791-805.

Wynstra, F., Corswant, F. V. and Wetzels, M. 2010."In chains?An empirical study of antecedents of supplier product development activity in the automotive industry."Journal 
of Product Innovation Management27(5): 625-639.

Wang, M-C and Chen, M-H.2015."The more, the better? The impact of closure collaboration network and network structures on technology-based new ventures' performance." $R \& D$ Management, article first published online:4 MAR 2015. DOI: 10.1111/radm.12129

\section{Appendix}

Figure 1 strategies

Theoretic framework for network embeddedness and the formulation of product innovation

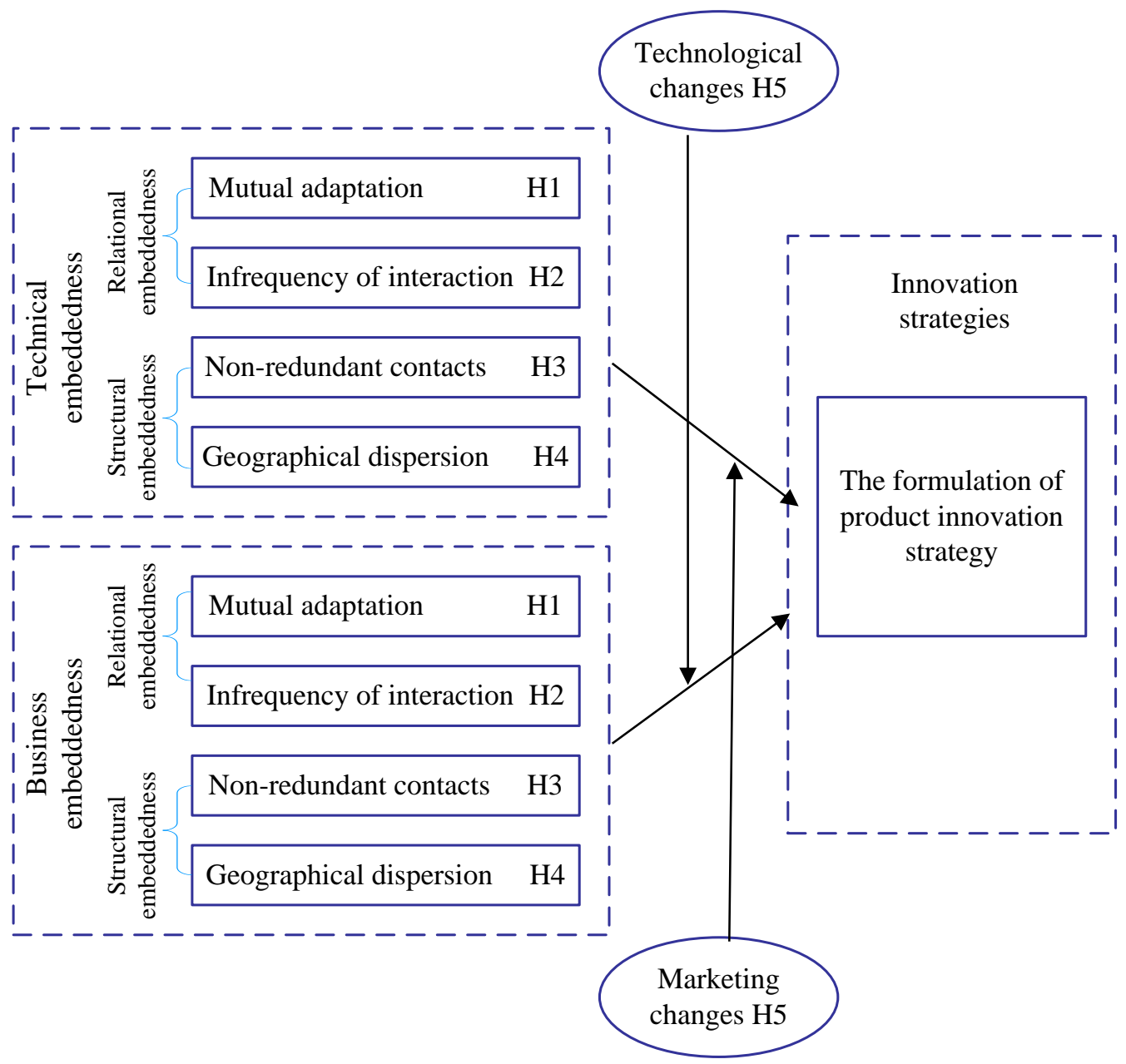

Table 1 Measures and exploratory factor analysis

\begin{tabular}{|l|l|l|l|l|l|}
\hline Measure items & Source of measures & & \multicolumn{3}{|l|}{ Factor loading } \\
\hline Network embeddedness (mutual adaptation) & & mean & Df. & $\begin{array}{l}\text { Technical } \\
\text { embeddedness }\end{array}$ & $\begin{array}{l}\text { Business } \\
\text { embeddedness }\end{array}$ \\
\hline
\end{tabular}




\begin{tabular}{|c|c|c|c|c|c|c|}
\hline \multicolumn{2}{|c|}{$\begin{array}{l}\text { 1. The degree to which the business has } \\
\text { changed its work patterns because of } \\
\text { relationships with its most important } \\
\text { technical partners? }\end{array}$} & \multirow{4}{*}{$\begin{array}{l}\text { Measures were devised } \\
\text { by Anderssonet al. } \\
\text { (2002). Some changes } \\
\text { were made to suit the } \\
\text { setting of this research }\end{array}$} & 4.66 & 1.162 & 0.054 & 0.927 \\
\hline \multicolumn{2}{|c|}{$\begin{array}{l}\text { that have direct contacts with } \\
\text { technical partners }\end{array}$} & & 4.69 & 1.232 & 0.079 & 0.926 \\
\hline \multicolumn{2}{|c|}{$\begin{array}{l}\text { changed its work patterns because of } \\
\text { relationships with the most important } \\
\text { external customers and suppliers? }\end{array}$} & & 4.88 & 1.106 & 0.936 & 0.043 \\
\hline \multicolumn{2}{|c|}{$\begin{array}{l}\text { 4. Number of different functional areas } \\
\text { that have direct contacts with } \\
\text { customers and suppliers }\end{array}$} & & 4.83 & 1.165 & $\mathbf{0 . 9 3 1}$ & 0.092 \\
\hline & & & \multicolumn{4}{|c|}{$\mathrm{KMO}=0.720$, Bartlett's test of Sphericity $\mathrm{P}<0.001$} \\
\hline \multicolumn{2}{|c|}{ Product innovation strategies (1-low to 7 high) } & & Mean & Df. & \multicolumn{2}{|c|}{ Product Innovation } \\
\hline & \multirow{2}{*}{$\begin{array}{l}\text { How important is product innovation } \\
\text { to firm's strategy formulation? } \\
\text { Compared to major competitors the } \\
\text { aggressiveness of product innovation } \\
\text { in terms of the speed of innovations } \\
\text { when formulating firm's strategies }\end{array}$} & \multirow{5}{*}{ 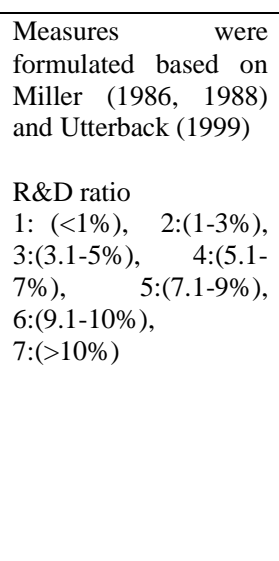 } & 5.47 & 1.482 & \multicolumn{2}{|c|}{0.848} \\
\hline $\begin{array}{l}\text { to firm's strategy formulation? } \\
\text { Compared to major competitors the } \\
\text { aggressiveness of product innovation } \\
\text { in terms of the speed of innovations } \\
\text { when formulating firm's strategies }\end{array}$ & & & 5.05 & 1.260 & \multicolumn{2}{|l|}{0.919} \\
\hline \multicolumn{2}{|c|}{$\begin{array}{l}\text { aggressiveness of product innovation } \\
\text { in terms of the degree of innovation } \\
\text { (differentiation or cost leadership) } \\
\text { when formulating firm's strategies }\end{array}$} & & 5.18 & 1.288 & \multicolumn{2}{|l|}{0.888} \\
\hline \multicolumn{2}{|c|}{$5 \quad$ growull } & & 5.14 & 1.334 & \multicolumn{2}{|l|}{0.809} \\
\hline \multicolumn{2}{|c|}{$\begin{array}{l}\text { 5. The ratio of R\&D investment in new } \\
\text { product development to sales revenue }\end{array}$} & & 5.12 & 1.143 & \multicolumn{2}{|l|}{$\mathbf{0 . 9 3 9}$} \\
\hline & & & \multicolumn{4}{|c|}{$\mathrm{KMO}=0.851$, Bartlett's test of Sphericity $\mathrm{P}<0.001$} \\
\hline \multicolumn{2}{|c|}{$\begin{array}{l}\text { Change dynamics (1- strongly disagree to } 7 \\
\text { strongly agree) }\end{array}$} & & Mean & Df. & $\begin{array}{l}\text { Technical } \\
\text { environmental } \\
\text { dynamics }\end{array}$ & $\begin{array}{l}\text { Business } \\
\text { environmental } \\
\text { dynamics }\end{array}$ \\
\hline \multirow[t]{5}{*}{$\begin{array}{l}\text { Technical } \\
\text { Dynamics }\end{array}$} & $\begin{array}{l}\text { 1. The speed of technological } \\
\text { development changes fast }\end{array}$ & $\begin{array}{l}\text { Measures were devised } \\
\text { based on Jaworski and }\end{array}$ & 4.88 & 1.312 & 0.771 & 0.322 \\
\hline & $\begin{array}{l}2 . \text { Technological changes } \\
\text { provide promising } \\
\text { opportunities in our industry. }\end{array}$ & Kohli, (1993) & 5.05 & 1.378 & 0.847 & .290 \\
\hline & $\begin{array}{l}\text { 3.It is difficult to estimate what } \\
\text { the main trend of technological } \\
\text { development will be in five } \\
\text { years time }\end{array}$ & & 4.76 & 1.197 & 0.570 & 0.399 \\
\hline & $\begin{array}{l}\text { 4.A large number of new } \\
\text { product ideas have been made } \\
\text { possible through technological } \\
\text { breakthroughs in our industry }\end{array}$ & & 5.31 & 1.255 & 0.787 & 0.167 \\
\hline & $\begin{array}{l}\text { 5. Technological developments } \\
\text { are mainly radical in our } \\
\text { industry }\end{array}$ & & 5.74 & 1.177 & 0.822 & 0.024 \\
\hline \multirow[t]{6}{*}{$\begin{array}{l}\text { Marketing } \\
\text { dynamics }\end{array}$} & $\begin{array}{l}\text { 1.Customer's } \\
\text { changes very fast }\end{array}$ & & 4.59 & 1.418 & 0.274 & 0.737 \\
\hline & $\begin{array}{l}\text { 2. Our customers look for new } \\
\text { product all the time }\end{array}$ & & 4.64 & 1.460 & 0.270 & 0.841 \\
\hline & $\begin{array}{l}\text { 3.Many of our customers are } \\
\text { first time buyers }\end{array}$ & & 5.21 & 1.084 & 0.371 & 0.733 \\
\hline & $\begin{array}{l}\text { 4.New customers tend to have } \\
\text { new product-related needs }\end{array}$ & & 5.11 & 1.437 & 0.286 & 0.816 \\
\hline & $\begin{array}{l}\text { 5.We tend to attract new } \\
\text { customers }\end{array}$ & & 4.33 & 1.305 & -0.042 & 0.870 \\
\hline & & & KMO & $0.720, \mathrm{~B}$ & ett's test of Sphe & ity $\mathrm{P}<0.001$ \\
\hline
\end{tabular}


Table 2Results of construct reliability tests

\begin{tabular}{|c|c|c|c|c|c|}
\hline \multirow{2}{*}{ Variable categories } & \multirow{2}{*}{ Variables } & \multirow{2}{*}{$\begin{array}{l}\text { Cronbach's } \\
\text { alpha }\end{array}$} & \multicolumn{3}{|c|}{ Item-Total Correlation } \\
\hline & & & Mean & minimum & Maximum \\
\hline \multirow{2}{*}{$\begin{array}{l}\text { Network } \\
\text { embeddedness }\end{array}$} & $\begin{array}{l}\text { Technical } \\
\text { embeddedness }\end{array}$ & .841 & .726 & .726 & .726 \\
\hline & $\begin{array}{l}\text { Business } \\
\text { embeddedness }\end{array}$ & .857 & .751 & .751 & .751 \\
\hline $\begin{array}{l}\text { Product innovation } \\
\text { strategies }\end{array}$ & $\begin{array}{l}\text { Product } \\
\text { innovation }\end{array}$ & .923 & .808 & .708 & .894 \\
\hline \multirow{2}{*}{ Change dynamics } & $\begin{array}{l}\text { Technological } \\
\text { change } \\
\text { dynamics }\end{array}$ & .862 & .682 & .564 & .789 \\
\hline & $\begin{array}{l}\text { Market } \\
\text { change } \\
\text { dynamics }\end{array}$ & .890 & .737 & .666 & .840 \\
\hline
\end{tabular}


Table 3Descriptive statistics and correlations

\begin{tabular}{|c|c|c|c|c|c|c|c|c|c|c|c|c|c|c|c|c|c|}
\hline Variables & Mean & S.D. & 1 & 2 & 3 & 4 & 5 & 6 & 7 & 8 & 9 & 10 & 11 & 12 & 13 & 14 & 15 \\
\hline \multicolumn{18}{|l|}{ Control variables } \\
\hline 1. Region 1 & .230 & 0.42 & & & & & & & & & & & & & & & \\
\hline 2. Region 2 & .319 & 0.47 & $\begin{array}{l}-0.375 \\
* *\end{array}$ & & & & & & & & & & & & & & \\
\hline 3.Sectors & .471 & 0.501 & $\begin{array}{l}0.213 \\
* *\end{array}$ & $\begin{array}{l}-0.199 \\
* * *\end{array}$ & & & & & & & & & & & & & \\
\hline 4.Firm Age & 11.6 & 8.95 & -0.138 & -0.087 & $\begin{array}{l}-0.212 \\
* *\end{array}$ & & & & & & & & & & & & \\
\hline 5.Firm Size & 6.28 & 1.65 & $\begin{array}{l}-0.273 \\
* *\end{array}$ & 0.014 & $\begin{array}{l}-0.166 \\
*\end{array}$ & $\begin{array}{l}0.398 \\
* *\end{array}$ & & & & & & & & & & & \\
\hline \multicolumn{18}{|l|}{$\begin{array}{l}\text { Technical } \\
\text { Embeddedness }\end{array}$} \\
\hline $\begin{array}{l}\text { 6.Non-redundant } \\
\text { contacts }\end{array}$ & 1.11 & .422 & $\begin{array}{l}0.211 \\
* *\end{array}$ & -0.107 & 0.130 & -0.124 & -0.125 & & & & & & & & & & \\
\hline $\begin{array}{l}\text { 7.Infrequency of } \\
\text { interaction }\end{array}$ & .505 & .259 & -0.069 & -0.115 & 0.005 & $\begin{array}{l}-0.352 \\
* *\end{array}$ & -0.007 & -0.050 & & & & & & & & & \\
\hline $\begin{array}{l}\text { 8.Geographic } \\
\text { dispersion }\end{array}$ & 2.14 & 1.13 & -0.048 & ${ }^{-0.154}$ & 0.043 & 0.015 & $\begin{array}{l}-0.267 \\
* * *\end{array}$ & $\begin{array}{l}-0.197 \\
* *\end{array}$ & -0.142 & & & & & & & & \\
\hline $\begin{array}{l}\text { 9.Mutual } \\
\text { adaptation }\end{array}$ & 4.68 & 1.11 & $\begin{array}{l}0.188 \\
*\end{array}$ & $\begin{array}{l}-0.248 \\
* * *\end{array}$ & 0.135 & $\begin{array}{l}-0.150 \\
*\end{array}$ & -0.026 & $\begin{array}{l}0.179 \\
*\end{array}$ & 0.129 & -0.099 & & & & & & & \\
\hline \multicolumn{18}{|l|}{ Business } \\
\hline $\begin{array}{l}\text { 10.Non- } \\
\text { redundant } \\
\text { contacts }\end{array}$ & 1.08 & 0.398 & -0.101 & -0.048 & -0.051 & -0.070 & 0.133 & 0.095 & 0.005 & -0.064 & 0.129 & & & & & & \\
\hline $\begin{array}{l}\text { 11.Infrequency of } \\
\text { interaction }\end{array}$ & .483 & 0.292 & 0.014 & $\begin{array}{l}-0.240 \\
* *\end{array}$ & -0.068 & $\begin{array}{l}-0.300 \\
* * *\end{array}$ & -0.081 & -0.071 & $\begin{array}{l}0.767 \\
* * *\end{array}$ & -0.129 & 0.043 & -0.010 & & & & & \\
\hline $\begin{array}{l}\text { 12.Geographic } \\
\text { dispersion }\end{array}$ & 2.17 & 1.08 & -0.101 & -0.086 & $\begin{array}{l}0.151 \\
*\end{array}$ & 0.120 & -0.011 & $\begin{array}{l}-0.248 \\
* * *\end{array}$ & -0.131 & $\begin{array}{l}0.736 \\
* *\end{array}$ & -0.079 & -0.020 & $\begin{array}{l}-0.231 \\
* *\end{array}$ & & & & \\
\hline $\begin{array}{l}\text { 13.Mutual } \\
\text { adaptation }\end{array}$ & 4.85 & 1.06 & -0.060 & -0.079 & -0.140 & -0.130 & $\begin{array}{l}0.215 \\
* *\end{array}$ & $\begin{array}{l}0.163 \\
*\end{array}$ & $\begin{array}{l}0.153 \\
* * *\end{array}$ & $\underset{* *}{-0.263}$ & 0.145 & $\begin{array}{l}0.347 \\
* *\end{array}$ & 0.138 & $\begin{array}{l}-0.243 \\
* *\end{array}$ & & & \\
\hline \multicolumn{18}{|l|}{$\begin{array}{l}\text { Change } \\
\text { dynamics }\end{array}$} \\
\hline $\begin{array}{l}\text { 14.Technological } \\
\text { dynamics }\end{array}$ & 5.15 & 1.02 & 0.195 & $\begin{array}{l}-0.296 \\
* *\end{array}$ & $\begin{array}{l}0.397 \\
* *\end{array}$ & -0.282 & 0.079 & $\begin{array}{l}0.293 \\
* *\end{array}$ & $\begin{array}{l}0.303 \\
* * *\end{array}$ & -0.117 & $\begin{array}{l}0.232 \\
* *\end{array}$ & $\begin{array}{l}0.301 \\
* * *\end{array}$ & 0.201 & -0.005 & $\begin{array}{l}0.292 \\
* * *\end{array}$ & & \\
\hline $\begin{array}{l}\text { 15.Marketing } \\
\text { dynamics } \\
\text { Innovation } \\
\text { strategy }\end{array}$ & 4.78 & 1.12 & -0.108 & -0.225 & $\begin{array}{l}0.253 \\
* *\end{array}$ & -0.015 & 0.076 & $\begin{array}{l}0.244 \\
* * *\end{array}$ & 0.009 & $\begin{array}{l}0.166 \\
*\end{array}$ & 0.035 & $\begin{array}{l}0.248 \\
* *\end{array}$ & -0.059 & 0.012 & $\begin{array}{l}0.158 \\
* *\end{array}$ & $\begin{array}{l}0.542 \\
* * *\end{array}$ & \\
\hline $\begin{array}{l}\text { 16.Product } \\
\text { innovation }\end{array}$ & 5.19 & 1.14 & -0.019 & $\begin{array}{l}-0.251 \\
* *\end{array}$ & $\begin{array}{l}0.233 \\
* *\end{array}$ & 0.075 & $\begin{array}{l}0.167 \\
*\end{array}$ & $\begin{array}{l}0.154 \\
*\end{array}$ & 0.133 & -0.052 & $\begin{array}{l}0.524 \\
* *\end{array}$ & $\begin{array}{l}0.275 \\
* *\end{array}$ & 0.135 & 0.071 & 0.114 & $\begin{array}{l}0.380 \\
* *\end{array}$ & $\begin{array}{l}0.360 \\
* *\end{array}$ \\
\hline
\end{tabular}

* $\mathbf{P}<0.05$,

*** $\mathbf{P}<\mathbf{0 . 0}$ 
Table 4 Technical embeddedness, business embeddedness and the formulation of product innovation strategies

\begin{tabular}{|c|c|c|c|c|c|c|}
\hline \multirow{2}{*}{ Variables } & \multicolumn{6}{|c|}{ The formulation of product Innovation strategies } \\
\hline & Model 1( $\beta)$ & Model 2 ( $\beta$ ) & Model 3(ק) & Model 4(ß) & Model 5( $\beta)$ & 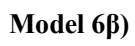 \\
\hline Constant & $4.415^{* * *}$ & $1.968^{* *}$ & $1.229^{*}$ & $2.932^{* * *}$ & $1.830^{* * *}$ & -.213 \\
\hline \multicolumn{7}{|l|}{ Control variables } \\
\hline Region 1 & -0.304 & -0.433 & -0.400 & -.246 & -0.087 & -0.266 \\
\hline Region 2 & $-0.602^{* *}$ & $-0.325^{*}$ & $-0.236^{*}$ & $-.446^{*}$ & -0.231 & 0.015 \\
\hline Sectors & $0.551^{* * *}$ & $0.496^{* * *}$ & $0.503^{* * *}$ & $.617^{* * *}$ & $0.677^{* * *}$ & $0.572^{* * * *}$ \\
\hline Firm age & 0.003 & $0.014^{+}$ & $0.021^{*}$ & 0.012 & $0.022^{*}$ & $0.030^{* *}$ \\
\hline Firm size & $0.119^{*}$ & $0.090^{+}$ & $0.094^{+}$ & $0.068^{+}$ & $0.056^{+}$ & $0.060^{+}$ \\
\hline \multicolumn{7}{|l|}{$\begin{array}{l}\text { Technical } \\
\text { embeddedness }\end{array}$} \\
\hline Mutual adaptation & & $0.526^{* * *}$ & & & & $.487^{* * *}$ \\
\hline $\begin{array}{l}\text { Infrequency } \\
\text { interaction }\end{array}$ & & $0.522^{*}$ & & & & $0.325^{+}$ \\
\hline $\begin{array}{l}\text { Non-redundant } \\
\text { contacts }\end{array}$ & & & $0.293^{+}$ & & & $0.319^{*}$ \\
\hline $\begin{array}{l}\text { Geographic } \\
\text { dispersion }\end{array}$ & & & 0.037 & & & -0.045 \\
\hline \multicolumn{7}{|l|}{$\begin{array}{l}\text { Business } \\
\text { embeddedness }\end{array}$} \\
\hline Mutual adaptation & & & & $0.332^{* * *}$ & & $0.118^{+}$ \\
\hline $\begin{array}{l}\text { Infrequency } \\
\text { interaction }\end{array}$ & & & & $0.695^{*}$ & & $1.161^{* *}$ \\
\hline $\begin{array}{l}\text { Non-redundant } \\
\text { contacts }\end{array}$ & & & & & $0.594^{* *}$ & $0.520^{* *}$ \\
\hline $\begin{array}{l}\text { Geographic } \\
\text { dispersion }\end{array}$ & & & & & 0.090 & 0.189 \\
\hline \multicolumn{7}{|l|}{ Model summary } \\
\hline $\mathrm{R}^{2}$ & 0.151 & 0.386 & 0.404 & 0.234 & 0.291 & 0.488 \\
\hline Adjusted $\mathrm{R}^{2}$ & 0.126 & 0.365 & 0.373 & 0.207 & 0.254 & 0.448 \\
\hline $\mathrm{F}$ & $6.240^{* * *}$ & $18.315^{* * *}$ & $12.944^{* * * *}$ & $8.889^{* * *}$ & $7.847^{* * * *}$ & $12.315^{* * *}$ \\
\hline
\end{tabular}

$\mathrm{N}=182 ; \quad{ }^{+} \mathrm{P}<0.10 ;{ }^{*} \mathrm{P}<0.05 ;{ }^{* *} \mathrm{P}<0.01 ;{ }^{* * *} \mathrm{P}<0.001$ 
Table 5 The moderating effect of change dynamics on the relationship between network embeddedness and the formulation of product innovation strategies

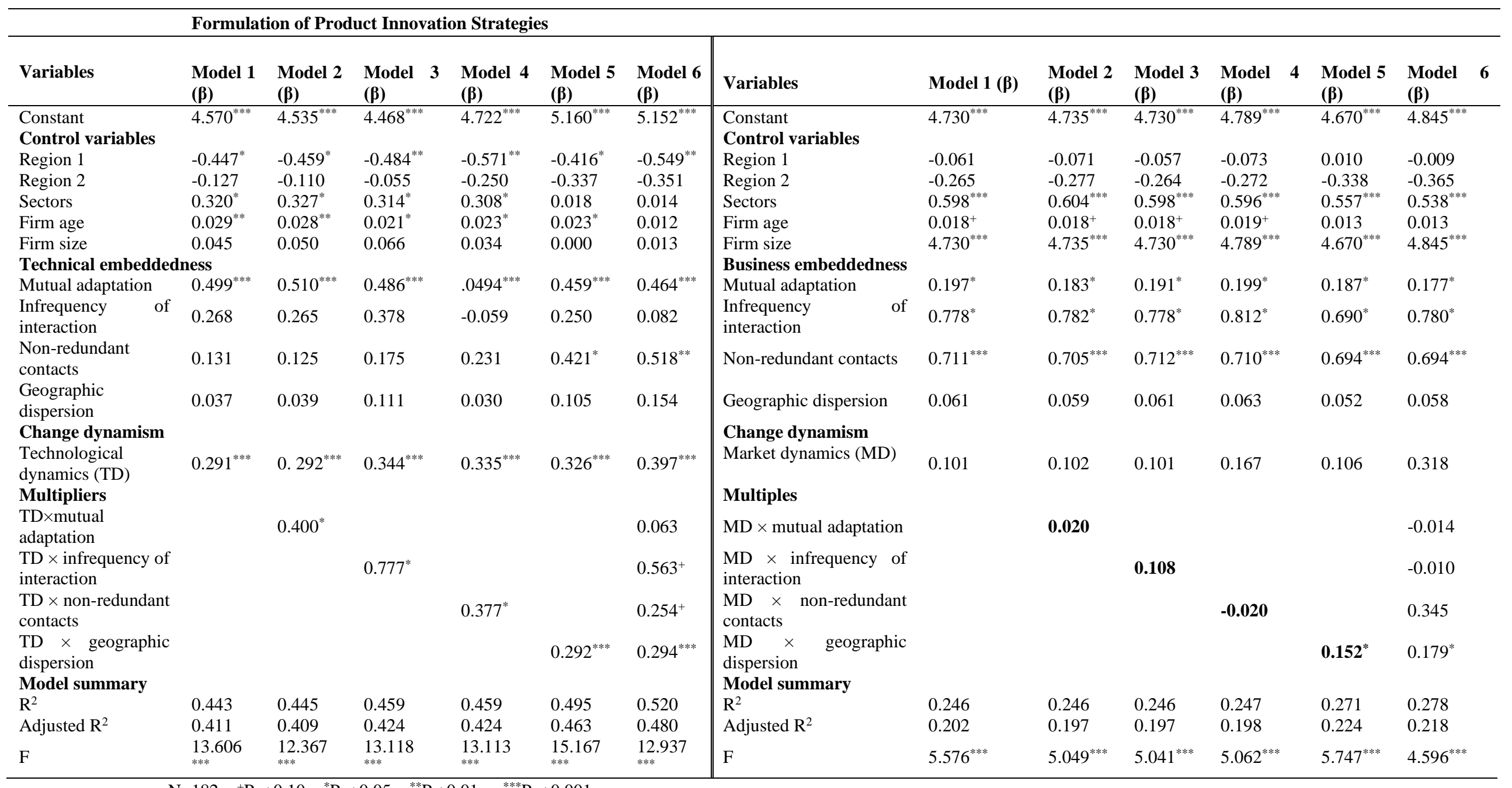

$\mathrm{N}=182 ;{ }^{+} \mathrm{P}<0.10 ; \quad{ }^{*} \mathrm{P}<0.05 ;{ }^{* *} \mathrm{P}<0.01 ; \quad{ }^{* * * *} \mathrm{P}<0.001$ 